\title{
Different modes analysis of College Student Management
}

\author{
Yue haifeng
}

College of petroleum and chemical engineering, Dongying Vocational College Shandong , Dongying, 257091

Keywords: College student management; Individualized management; open management mode

\begin{abstract}
:
the quality of running a college for colleges not only rely on the student's academic level to measure, college student management also plays an irreplaceable role. The development of college student management can help to cultivate students with full development of morality, wisdom, physique and aesthetics, and enhance students' competitiveness. In this paper, starting with the college student management problems, we introduce the application effects of different college student management models.

Student management as an important part of the daily work of college, is the base of effective maintenance for normal teaching order of college, and protecting the healthy development of the student. Currently, due to differences in the systems and features of college, some difference exists in their management for education and teaching. Among a period of time, the traditional management model played an important role, and successfully cultivated the student meets the social needs. With the development of the times, the drawbacks of this management model is gradually revealing, the cultivation goal of college is to deliver more students with high and comprehensive quality, the traditional student management model has been unable to meet development needs. Since college is increasing the enrollment, the quality of students cultivated by college is effected, the college which stick to the traditional management model has been unable to meet the demand for talent of the society, which requires workers of student managing to explore new management strategies, so as to be better at cultivating students with high quality for college. The college students' management model is acted as research perspective in this paper to analyze the problems appeared in management for college students, the effect of college with different student management models are proposed.
\end{abstract}

\section{the problems in college student manage}

\section{A The lagging of student management concepts}

Essence of international competition in the 21st century is the talent competition. China's universities is the cradle of train high-quality personnel, and their responsibilities are as heavy as Mount Tai. If it wants to accomplish this sacred mission, colleges must create a scientific and rational management philosophy. The serve object of colleges is student, and the purpose of colleges and universities' work should be student service. Due to the impact of different concepts in long term planning system, the colleges became active educators, and students are in the position of passive education and management. This traditional management model excessively pursues unity but ignores the development of the needs of individual student. This model pursues the same style and pace, making the students in each colleges and universities dose not differ significantly from all aspects of thinking, knowledge structure and so on. With the rapid development of society, the drawbacks of traditional management model gradually are revealed, which neglects the discovery 
and development of students' personality, denies the opportunity of students to show themselves creative, and seriously restricts the development of students.

\section{$B$ The student management system is incomplete}

Currently, the student management system adopted by majority of colleges is the management model under the economic system, with a strong administrative tendency. According to the principle of separating party and government, student management system can be divided into ideological education and administrative management. Administrative system is composed of the Office of Student Management in Department, Department of student affairs, class committee of various classes, ideological education system constituted of the Communist Youth League, the branch League in Departments, and Student Affairs. The leader of managing ideological work of the student and the leader of student management are in charge of these two management systems in college. The student management system seems to be clearly mandated and complete, in the actual management. The staff are often too busy to handle everything, due to the incomplete system. With the reform of the social and educational system, new content is injected into the functions of higher education, colleges should be based on the law of the trading system to cultivate talent of high-quality to adapt to social development.

\section{$C$ The management mode is singleness}

Modern management philosophy emphasizes the dynamic management mode, dynamic management is pursued in modern management of college at both size and complexity, which requires managers to pay attention to changes in internal and external conditions of the system, and information collection, in accordance with the actual situation to regulate timely, so as to ensure that management mechanisms meet the change demand of objective things and achieve a predetermined goal of management. College administrators have to re-examine the purpose of college education based on social development and needs of talents, the management model chosen to be dynamic and open, so that creating a good learning atmosphere for students. The self-management awareness and creativity of students have to be valued in open management mode.

\section{Application effect of different student management mode in college}

A great job to provide convenience for students is the premise for the college to cultivate the talent with comprehensive development, the traditional student management model is based mainly on the student's external management, with external means to regulate the students in macro. The traditional student management mode cannot motivate the personality of students to show up, the needs of self-education and administration of students are unable to be meet, the creative development of student is curbed to some extent.

\section{A Individualized student management mode}

Individualized management concept

There doesn't exist two identical leaves in the world, not two identical people as well. Due to students with differences in upbringing environment, family influence, personal experience, etc. each student is unique from the aspect of the energy of stored knowledge, character and others. The management for students is not to eliminate student characteristics and individual differences, but to ensure that each student's originality have been perfectly expressed. For a long period of time, meticulous ideological education is varied based on specific situation of students in the 
management for students, mobilization is usually used as a major work practice, but collective interests is emphasized, which ignore the development of uniqueness of individual students. With the gradual deepening of social reform, the issues of graduated students in the social functions is increasing, the new trend of college student management is emerged, it's a transition from collective instilling to guiding the individual, so as to motivate the individualized education of pertinence, flexible management and service model is adopted according to each student's actual situation. Individualized management model is to promote the development of students 'personality with reasonable strategy, and analyze, tackle the problems encountered by the students; meanwhile, scientific management and ways are utilized to promote students' self-management and education, so as to stimulate its internal potential development.

Individualized management method

When college is managing the student, aim to value the development of individual st udents to maximum, the management of different forms can be given in a variety of sector s. The college management staff must work with innovation, embrace the changes in educat ion reform, and further the management based on the students.

case counselling

Case counselling is utilizing the corresponding counselling method depending on diffe rent students. Case counselling regards students as objects, in accordance with the basic inf ormation and activity records to provide systematic and planned counselling for students, so as to achieve spontaneous counselling by providing counseling assistance. Managers of a si ncere attitude to help students develop their potential, and choose the best way to deal with the immediate problems consciously. In the actual case-counselling, not to simplify student behavior, a combination of factors for appearance of undesirable phenomenon should be in -depth studied, the main cause of problems need to be highlighted, some students are withd rawn and does not like to communicate with people, may be caused by psychological syste $\mathrm{m}$ or due to inharmonious family relationship or other factors. Based on the above issues $\mathrm{t}$ o counsel for students, firstly, sympathize with and support him, followed by being a good listener to allow him to express the dissatisfaction and complaining; when the students cal $\mathrm{m}$ down, discussing with him based on the actual situation to help him solve the problem. The students as a fresh graduate encounters a turning point between college and society, at this time, they will run into a lot of problems in the social adaptability of both physical a nd psychological, these issues throughout their daily life and study, college administrators $\mathrm{m}$ ust be actively involved to offer the appropriate care, and help students to solve problems on the basis of actual situation.

(2)personal file creation

Since enrolled in the college, the college administrators will conduct a detailed inv estigation on the students to grasp more comprehensive situation of students. Firstly, throug $\mathrm{h}$ the files of students and communication with student and other forms, to grasp basic info rmation like gender, ethnicity, family, hobbies and other, different types of files have to be established, such as: files of students with specialty, files of students with poverty; while, scientific psychological tests can be expanded for students to create a mental file, so as to facilitate the implementation of targeted education and management for students. Dynamic $\mathrm{m}$ anagement of student records with developing vision is to add new content for all stages of the development of student in future practical work, and grasp student thinking and behavi or in comprehensive and all-round way.

(3) establishment of a rational incentive system 
It is an important responsibility for managers in college to guide benign behavior o f student and control bad behavior of student reasonably. Mechanism for individual behavior research is based on learning theory to explore human behavior, all the focus is put on in centives action. Depending on different learning theories to develop helpful methods in vari ous forms. For example: according to constraint learning theory to emphasize the associatio $\mathrm{n}$ between stimulation and reflection, if the desired behavior is produced, a reward should $\mathrm{b}$ e timely provided, to further increasing the occurrence frequency of the behavior, and motiv ate the formation of good behavior. Setting an example as exemplary role model to prompt other students generate admiration. Emulate will motivate students to learn proper behavior, so as to achieve the effect of role models.

(B) Open management mode

\section{$B$ The concept of open management mode}

Most of the traditional management model for student is limited within the college, ignoring factors outside colleges, in order to adapt to the development of 21st century knowledge and economy era, the college administration should reform the closed management model into an open management model. The college administrator have to be brave to accept the test of the new situation, to reform the traditional management of indoctrination and mandatory, and change the management way from the past managed-oriented toward service-oriented. It is necessary to be more comprehensive for understanding the situation and ideological problems of student, so as to make up for the defects of traditional management model, so that students is developing in a pleasant environment. Open management model regards social and family environment of student as an organic combination part, defaults that personal life impacted by environment a lot, the majority of individuals' problems are affected by environmental infections, especially family of personal life is primary factor affecting personal development.

\section{Open student management method}

Student apartments are the new field of college student management in new period, but also an important way for students to develop social service awareness in practice and enhance the sense of social responsibility. With the growing scale of college, the socialization reform of rear services is deeper, which resulting in a corresponding change in student apartment management regimes. With community resources to build socialized students' apartments, the activity scope of student has changed the traditional pattern of single point-line, forming a unique campus apartment. Ideological education, psychological counselling, apartment culture establishment, life and study consulting are integrated into student apartments. The student apartments organization is constructed, wherein, student discipline committee is the organization managed by the student, so as to form a student self-management system composed of director, residence advisor, dormitory leader, then combined with apartments student party organizations, the duty of residence advisor and dormitory leader is to participate in recording of the students, take care of the health of the student and safety maintenance

work, democratic supervision management model is preferred, and have to communicate with students to help them resolve conflicts in all aspects timely.

\section{Conclusion}

In short, college student management is a long and arduous task. As the manager of college student work who must have the management philosophy of advancing with the times, and select the best student management mode according to the actual situation of universities, so as to make the greatest contribution to cultivate the all-round talent. 


\section{References:}

[1] Wang Yu. New exploration of student work management model in independent college [J] Education Forum, 2012, (2): 71-73.

[2] Wang Lin. Existing problems and coping strategies for college student management [J] Chinese Information, 2014, (4): 73.

[3] Wang Yu. How to do the management work of university students [J] new curriculum (educational academy), 2012, (12): 297.

[4] Wu Ke. Discussion on the "flexible management" strategy for College student management [J] The days (the second half), 2012, (10): 157.

[5] Zeng Zheng. The application of management theory in the college student management [J] Chinese market, 2014, (10): 143-144.

[6] $\mathrm{Xu} \mathrm{Na}$. the use of modern theory of business to explore the innovative model for College Student Management [J] literary education (below), 2014, (7): 136.

[7] Li Jindong, Liu Zhenping. Innovation exploration of college student management in the new era [J] Journal of Changchun College of education, 2011, (12): 23-24.

[8] Wang Jiancai, Xu Feng, Wang Feihu, et al. the application of information model for college student management [J] Modern computer (Universal Edition), 2013, (8): 70-73. 